\title{
TINGKAT KESUBURAN PERAIRAN KOLAM AGROWISATA UIR DITINJAU DARI KONSENTRASI KLOROFIL-a PHYTOPLANKTON DI KECAMATAN SIAK HULUKABUPATEN KAMPARPROVINSI RIAU
}

\section{Level of Productivity in the Water of UIR Agrowisata Pool Reviewed from the Concentration of Chlorofill-a Phytoplankton in Siak Hulu District Kampar Regency of Riau Province}

\author{
Muhammad Hasby \\ Staf Pengajar Program Studi Budidaya Perairan \\ Fakultas Pertanian Universitas Islam Riau \\ Email: hasbi_muhammad@agr.uir.ac.id \\ [Diterima: Desember 2016; Disetujui: Maret 2017]
}

\begin{abstract}
This study aims to determine the level of water fertility in the UIR Agro-tourism pond in the District of Siak Hulu, Kampar Regency, Riau Province based on the concentration of chlorophyll-a phytoplankton. The study was carried out for 6 months in the Agro-tourism pond in Riau Islamic University. Analysis of water fertility in situ and ex-situ. The parameters measured were chlorophyll-a phytoplankton concentration and water quality. The method used is a case study (survey). The treatment in this study was 3 replications in one week on the clock and the same pool sequence. The results showed that the pond fertility rate of UIR Agro-tourism was quite productive, namely chlorophyll-a concentration of 1-20 $\mu \mathrm{g} / 1$ with an abundance of phytoplankton of 104 cells / 1 .
\end{abstract}

Keywords: Chlorophyll-a, Phytoplankton, Aquatic fertility.

\begin{abstract}
ABSTRAK
Penelitian ini bertujuan untuk mengetahui tingkat kesuburan perairan di kolam Agrowisata UIR di Kecamatan Siak Hulu Kabupaten Kampar Provinsi Riau berdasarkan konsentrasi klorofil-a phytoplankton.Penelitian dilakukan selama 6 bulan di perairan kolam Agrowisata Universitas Islam Riau. Analisis kesuburan perairan secara in situ dan ex situ. Parameter yang diukur yaitu konsentrasi klorofil-aphytoplankton dan kualitas air. Metode yang digunakan studi kasus (survei). Perlakuan dalam peneitian ini sebanyak 3 kali ulangan dalam rentang waktu selama satu minggu pada jam dan urutan kolam yang sama.Tingkat kesuburan perairan kolam Agrowisata UIR cukup produktif yaitu konsentrasi klorofil-a sebesar 1-20 $\mu \mathrm{g} / \mathrm{l}$ dengan kelimpahan phytoplankton sebesar $10^{4} \mathrm{sel} / \mathrm{l}$.
\end{abstract}

Kata kunci : Klorofil-a, Phytoplankton, Kesuburan perairan.

\section{PENDAHULUAN}

Usaha budidaya ikan dilakukan pada kolam-kolam dengan sumber air berasal dari air hujan, air sungai, air tanah dan air irigasi.Salah satu fasilitas perairan kolam yang ada di Universitas Islam Riau adalah kolam Agrowisata UIR di Kecamatan Siak Hulu Kabupaten Kampar Propinsi Riau. Untuk melihat bagaimana kondisi lingkungan dan pengaruhnya terhadap biota lingkungan perairan kolam Agrowisata UIR maka diperlukan data kualitas air, yang mencakup penelitian terhadap kondisi fisika, kimia dan biologi. Pengukuran parameter biologi perairan yang digunakan adalah organisme phytoplankton,keberadaan phytoplankton sangat mempengaruhi kehidupan organisme lainnya di perairan. Menurut Sediady dan Lusikooy (1991) bahwa phytoplankton merupakan komponen utama dalam mata rantai makanan yang berkaitan erat dengan sumberdaya perikanan di suatu perairan. Phytoplankton yang mengandung klorofiladimanfaatkan sebagai sumber energi bagi organisme diperairan.Klorofil-a phytoplankton dapat dijadikan indikator ketersediaan makanan bagi organisme lain, seperti ikan yang bersifat herbivor sebagai sumber makanannya. 
Konsentrasi klorofil-a sendiri memiliki hubungan yang positif terhadap kelimpahan phytoplankton di perairan.

Salah satu cara untuk mengetahui kondisi awal tingkat kesuburan perairan kolam Agrowisata UIR adalah dengan mengukur kosentrasi klorofil-a phytoplankton yang bisa menjadi indikator bagi kesuburan perairan. Oleh sebab itu diperlukan informasi tentang kondisi perairan ditinjau dari konsentrasi klorofil-a phytoplankton, karena kesuburan perairan pada hakekatnya ditentukan oleh konsentrasi klorofila phytoplanktondan parameter kualitas perairan yang mempengaruhi konsentrasi klorofil-a phytoplankton untuk mendukung kegiatan perikanan di perairan kolam Agrowisata UIR.

\section{METODE PENELITIAN}

Penelitian dilakukan selama 6 bulan, yaitu mulai pada bulan November 2015 sampai dengan selesai Mei 2016 di perairan kolam Agrowisata UIR di Kecamatan Siak Hulu Kabupaten Kampar Propinsi Riau.

Alat yang digunakan dalam penelitian ini terdiri dari bahan-bahan kimia, seperti amilum, K.I alkaline, asamsulfat, tio sulfat, aquades, Indikator $\mathrm{PP}, \mathrm{Na}_{2} \mathrm{CO}_{3}$, yang digunakan untuk mengukur karbondioksida bebas dan oksigen terlarut, ember, wadah sampel, alat tulis, vakum pump, milipore filter, spektronik 21 serta alatalat untuk pengukuran parameter fisika, kimia dan biologi.Adapun bahan yang digunakan selama penelitian adalah perairan kolam Agrowisata UIR.

Metode yang digunakan adalah survei (studi kasus) dimana klorofil-a fitoplankton sebagai kasus, dipelajari secara intensif dan mendetail. Sampel diambil pada pukul $10.00-$ 14.00 Wib, sebanyak 3 kali ulangan dalam rentang waktu selama satu minggu pada jam dan urutan kolam yang sama.

\section{Parameter Yang Diamati}

Parameter yang diamati dalam penelitian ini adalah konsentrasi klorofil-aphytoplankton dan kualitas air. Kelimpahan phytoplankton ditentukan dengan menggunakan rumus menurut APHA (1989), yaitu :

$$
\mathbf{N}=\mathbf{Z} \quad \mathrm{X} \frac{\mathbf{X}}{\mathrm{Y}} \times \frac{1}{\mathrm{~V}}
$$

Dimana :

$\mathbf{N}=$ Kelimpahan phytoplankton (sel/l)

$\mathbf{V}=$ Volume air yang disaring (50 1)

$\mathbf{X}=$ Volume air yang tersaring $(25 \mathrm{ml})$

$\mathbf{Y}=$ Volume satu tetes pipet $(0,05 \mathrm{ml})$

$\mathbf{Z}=$ Jumlah individu yang ditemukan (sel)

Konsentrasi klorofil-a dihitung dengan persamaan Vollenweider 1969 (dalam Boyd, 1979) sebagai berikut :

\section{Klorofil-a $(\mu \mathrm{g} / \mathrm{l})=11,9\left(\mathrm{~A}_{665}-\mathrm{A}_{750}\right) \times \mathrm{V} / \mathrm{L} \times$ $1000 / \mathrm{S}$}

Dimana :

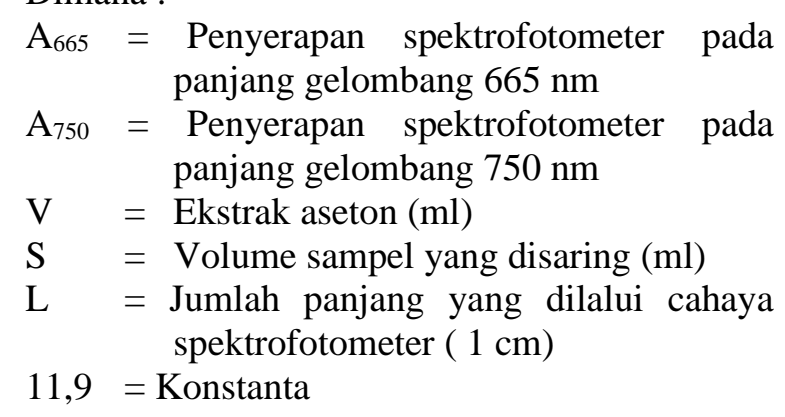

\section{Analisis Data}

Data kelimpahan phytoplankton dan kandungan klorofil-a serta parameter kualitas air yang diperoleh ditabulasikan dalam bentuk tabel dan digambarkan dalam bentuk grafik, kemudian dianalisis dan dibahas secarta deskriptif.

\section{HASIL DAN PEMBAHASAN}

\section{Konsentrasi Klorofil-a}

Adapun rata-rata hasil pengukuran klorofil-a selama penelitian berkisar antara 9,90$14,81 \mu \mathrm{g} / \mathrm{l}$.

Tabel 1. Hasil Pengukuran Konsentrasi Klorofil-a

\begin{tabular}{cccc}
\hline \multirow{2}{*}{$\begin{array}{c}\text { Pengambilan } \\
\text { ke - }\end{array}$} & \multicolumn{3}{c}{ Kolam } \\
\cline { 2 - 4 } & $\mathrm{I}$ & $\mathrm{II}$ & $\mathrm{III}$ \\
\cline { 2 - 4 }$(\mu \mathrm{g} / \mathrm{l})$ \\
\hline 1 & 7,73 & 15,22 & 9,98 \\
2 & 13,60 & 14,73 & 10,15 \\
3 & 12,56 & 14,48 & 9,56 \\
\hline Jumlah & 33,89 & 44,43 & 29,69 \\
\hline Rata-rata & 11,29 & 14,81 & 9,90 \\
\hline Sumber : Data Primer & &
\end{tabular}


Rata-rata konsentrasi klorofil-a pada masing-masing kolam dapat dilihat pada Gambar 1.

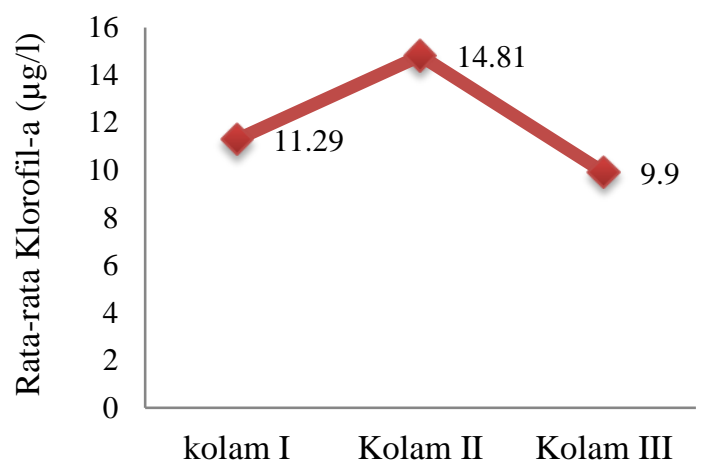

Gambar1.Rata-rata Kelimpahan Konsentrasi Klorofil-a $(\mu \mathrm{g} / \mathrm{l})$

Berdasarkan gambar 1 terlihat bahwa rata-rata konsentrasi klorofil-a pada setiap kolam di perairan kolam Agrowisata UIR menunjukkan nilai yang bervariasi. Variasi konsentrasi klorofil-a di perairan kolam Agrowisata UIR disebabkan karena letak lokasi masing-masing kolam pengamatan yang berbeda-beda dengan intensitas cahaya matahari yang berbeda pula, serta rentang waktu antar pengambilan sampel pada masing-masing kolam yang juga berbeda sehingga cenderung memiliki perbedaan parameter kualitas perairan yang diduga sebagai faktor penentu kelimpahan phytoplankton dan tinggi rendahnya konsentrasi klorofil-a phytoplankton di perairan. Hal ini sesuai dengan pendapat Nybakken (1992) yang mengatakan bahwa konsentrasi klorofil-a sangat bergantung pada waktu dan intensitas cahaya matahari. Selanjutnya Hatta (2002) menegaskan bahwa sebaran dan tinggi rendahnya konsentrasi klorofil-a sangat terkait dengan kondisi perairan itu sendiri.

\section{Jenis dan Kelimpahan Phytoplankton}

Jenis Phytoplankton yang ditemukan selama penelitian di perairan kolam Agrowisata UIR terdapat 3 kelas yang terdiri dari Bacillariophyceae (13 jenis), kelas Cyanophyceae (8 jenis) dan kelas Chlorophyceae (7 jenis). Jenis yang paling banyak ditemukan adalah dari kelas Bacillariophyceae. Banyaknya jenis phytoplankton dari kelas Bacillariophyceae diduga karena pada perairan kolam Agrowisata UIR banyak terdapat ranting-ranting kayu yang terdapat di kolam dan menjadi tempat hidup yang baik untuk jenis Bacillariophyceae. Hal ini sesuai dengan pendapat Sachlan (1980) yang menyatakan bahwa kelas Bacillariophyceae banyak dijumpai di perairan karena organisme ini hidup sebagai diatom di lapisan hypolimnion.

Jika dilihat dari jumlah jenis organisme phytoplankton yang ditemukan maka jenis terbanyak adalah Raphidonema nivale (kelas Chlorophyceae) sebanyak 2265 sel/l, Pleurotaenium trabecula (kelas Chlorophyceae) sebanyak $1707 \mathrm{sel} / \mathrm{l}$, Oscillatoria formosa (kelas Cyanophyceae) sebanyak 1678 sel/l) dan lainlain. Sachlan (1980) menyatakan bahwa jenis Chlorophyceae merupakan algae yang terbesar yang terdapat di perairan tawar. Selanjutnya Odum (1971) berpendapat bahwa penyebaran phytioplankton di daerah perairan terbuka umumnya terdiri dari 3 (tiga) jenis yaitu algae hijau (Chlorophyceae), diatome (Bacillariophyceae) dan algae biru (Cyanophyceae).

\section{Kelimpahan Phytoplankton}

Berdasarkan penelitian di perairan kolam Agrowisata UIR didapat kelimpahan phytoplankton rata-rata berkisar antara 9.932$12.770 \mathrm{sel} / \mathrm{l}$.

Tabel 2. Kelimpahan Phytoplankton di Perairan Kolam Agrowisata UIR Selama Penelitian

\begin{tabular}{cc}
\hline \multirow{2}{*}{ Kolam } & Kelimpahan Phytoplankton \\
\cline { 2 - 2 } & (Sel/1) \\
\hline I & 11.104 \\
II & 12.770 \\
III & 9.932 \\
Jumlah & 33.806 \\
Rata-rata & $11.268,667$ \\
\hline Sumber : Data Primer &
\end{tabular}

Tingginya kelimpahan phytoplankton pada kolam II (12.770 sel/l) diduga disebabkan karena kolam pengamatan merupakan kolam yang terletak pada kawasan terbuka sehingga penetrasi cahaya matahari dapat langsung menembus ke permukaan perairan. Hal ini juga ditunjukkan dengan tingginya kandungan oksigen terlarut sebesar $4,88 \mathrm{mg} / \mathrm{l}$ yang berasal dari aktifitas fotosintesis phytoplankton di perairan kolam Agrowisata UIR. Boyd (1979) menyatakan bahwa besarnya kelimpahan phytoplankton akan menaikkan konsentrasi $\mathrm{O}_{2}$ terlarut, sedangkan kolam III dan I merupakan 
kolam dengan kelimpahan phytoplankton terendah $(9.932 \mathrm{sel} / \mathrm{l}$ dan $11.104 \mathrm{sel} / \mathrm{l})$. Hal ini disebabkan karena pada kedua kolam tersebut terdapat banyak pepohonan yang menghalangi penetrasi cahaya matahari yang masuk ke perairan sehingga proses fotosintesis oleh phytoplanktonkurang optimal.

Kelimpahan phytoplankton di suatu perairan terjadi akibat pemanfaatan nutrien, cahaya matahari dan suhu. Kelimpahan phytoplankton di suatu perairan dipengaruhi oleh berbagai faktor seperti intensitas cahaya, nutrien, $\mathrm{pH}$, oksigen terlarut dan karbondioksida (Boney, 1975).

\section{Parameter Lingkungan Perairan}

Rata-rata hasil pengukuran parameter kualitas air di perairan kolam Agrowisata UIR yaitu suhu antara $28,4-29,4{ }^{\circ} \mathrm{C}$, kecerahan berkisar antara 29-29,7 cm, derajat keasaman $(\mathrm{pH})$ berkisar antara 6-6,07, $\mathrm{O}_{2}$ terlarut berkisar antara 4,28-4,88 mg/l, $\mathrm{CO}_{2}$ bebas berkisar antara $5,26-5,76 \mathrm{mg} / \mathrm{l}$, nitrat berkisar antara 0,0667$0,0733 \mathrm{mg} / \mathrm{l}$ dan fosfat berkisar antara 0,0070 0,0083 mg/l disajikan pada Tabel 3 .

Tabel 3. Nilai Rata-rata Parameter Kualitas Perairan Kolam Agrowisata UIR Selama Penelitian

\begin{tabular}{lcccc}
\multicolumn{1}{c}{ Parameter Kualitas Air } & Satu-an & K I & K II & K III \\
\hline Fisika & & & & \\
- Suhu & ${ }^{\circ} \mathrm{C}$ & 28,6 & 29,4 & 28,4 \\
- Kecerahan & $\mathrm{cm}$ & 29,1 & 29,7 & 29,0 \\
\hline Kimia & & & & \\
- pH & - & 6,07 & 6,00 & 6,00 \\
- O O $_{2}$ terlarut & $\mathrm{mg} / \mathrm{l}$ & 4,29 & 4,88 & 4,28 \\
- - $_{2}$ bebas & $\mathrm{mg} / \mathrm{l}$ & 5,76 & 5,26 & 5,59 \\
- Nitrat $*$ & $\mathrm{mg} / \mathrm{l}$ & 0,0667 & 0,0733 & 0,0700 \\
- Fosfat $*$ & $\mathrm{mg} / \mathrm{l}$ & 0,0083 & 0,0070 & 0,0073 \\
\hline
\end{tabular}

Sumber : Data Primer dan Data Sekunder*

Suhu

Sebaran suhu bervariasi di setiap kolamnya. Suhu tertinggi terdapat pada kolam II yaitu $29,4^{\circ} \mathrm{C}$. Tingginya suhu pada kolam II disebabkan karena kolam II tersebut berada ditengah-tengah lokasi kolam Agrowisata UIR dengan permukaan yang lebih luas dan tidak terhalang oleh rimbunan pepohonan sehingga cahaya matahari dapat langsung menembus ke perairan. Berbeda halnya pada kolam III dan I yang merupakan kolam yang banyak terdapat vegetasi pepohonan di pinggir kolam. Tambaru (2003) menyatakan bahwa suhu yang sesuai untuk kehidupan phytoplankton berkisar 20$30^{\circ} \mathrm{C}$. Dari pendapat tersebut dapat dikatakan bahwa kisaran suhu yang diukur selama penelitian masih dalam kisaran suhu yang optimal bagi pertumbuhan phytoplankton di kolam Agrowisata UIR.

\section{Kecerahan}

Kolam III dan I merupakan kolam dengan tingkat kecerahan yang rendah. Rendahnya kecerahan di kedua kolam ini disebabkan karena banyaknya ranting-ranting pepohonan di pinggir kolam yang jatuh ke perairan sehingga menutupi permukaan perairan. Selain itu kurangnya cahaya matahari yang masuk ke kolam disebabkan karena pada kolam III dan I merupakan kolam yang ditutupi vegetasi pepohonan di pinggir kolam. Wellch (1984) menyatakan bahwa semakin tinggi tingkat kecerahan maka semakin dalam penetrasi cahaya matahari yang masuk ke perairan, sehingga mengakibatkan lapisan produktif lebih tebal dan produktifitas primer semakin tinggi.

Hal ini sejalan dengan penelitian bahwa kolam II merupakan kolam dengan tingkat kecerahan yang tinggi dan memiliki kelimpahan phytoplankton yang lebih besar. Kecerahan produktif apabila pinggan secchi mencapai kedalaman 20-40 cm dari permukaan (Chakroff, 1979). Berdasarkan pendapat tersebut kecerahan perairan kolam Agrowisata UIR masih mendukung kehidupan organisme akuatik terutama phytoplankton.

\section{pH}

Berdasarkan penelitian yang dilakukan nilai $\mathrm{pH}$ di perairan kolam Asgrowisata UIR masih tergolong baik. Hal ini didukung oleh pendapat Odum (1971) yang menyatakan bahwa 
perairan dengan $\mathrm{pH}$ 6-9 merupakan perairan dengan kesuburan yang cukup tinggi, karena memiliki kisaran $\mathrm{pH}$ yang dapat membantu dalam proses perombakan bahan organikyang ada dalam perairan menjadi mineral-mineral yang dapat diasimilasikan oleh organisme perairan khususnya phytoplankton.

\section{Oksigen Terlarut}

Tingginya kadar oksigen terlarut pada kolam II disebabkan karena kolam II berada di tengah-tengah lokasi kolam Agrowisata UIR dengan permukaan yang lebih luas dan tidak terhalang oleh rimbunan pepohonan sehingga cahaya matahari dapat langsung menembus ke perairan daripada kolam III dan I yang ditutupi vegetasi pepohonan. Hal ini memungkinkan terjadinya proses fotosintesis secara optimal di kolam II. Kelimpahan phytoplankton yang tinggi akan menghasilkan oksigen yang tinggi sebagai hasil dari proses fotosintesis (Simarmata, 2007).

\section{Karbondioksida Bebas}

Tingginya kadar karbondioksida di kolam I dan IIIkarena kedua kolam tersebut banyak ditutupi oleh vegetasi pepohonan di pinggir kolam. Hal ini menyebabkan kolam tersebut terlindungi dari sinarmatahari yang masuk ke perairan, sehingga pemanfaatan $\mathrm{CO}_{2}$ bebas oleh phytoplankton berkurang karena proses fotosintesis yang rendah.Sedangkan rendahnya kadar karbondioksida di kolam II disebabkan karena kolam tersebut merupakan kolam yang berada ditengah-tengah lokasi kolam Agrowisata UIR dengan permukaan perairan yang luas, sehingga memungkinkan masuknya cahaya matahari yang optimal. Oleh karena itu kolam ini merupakan kolam dengan tingkat fotosintesis tinggi yang menyebabkan phytoplankton membutuhkan kadar $\mathrm{CO}_{2}$ yang lebih banyak untuk proses berlangsungnya fotosintesis. Effendi (2003) menyatakan bahwa kadar $\mathrm{CO}_{2}$ bebas di perairan dapat mengalami penngurangan, bahkan hilang sama sekali akibat proses fotosintesis, evavporasi dan agitasi air.

\section{Konsentrasi Nitrat dan Fosfat}

Keberadaan kandungan nitrat dan fosfat di perairan kolam Agrowisata UIR diduga berasal dari perombakan bahan-bahan organik yang dibawa melalui proses sisa-sisa pemberian pakan terhadap ikan yang dipelihara di kolam. Selain itu bagian pinggir kolam merupakan daratan dengan tanah kuning yang banyak ditumbuhi pepohonan yang tumbuh di pinggir kolam, sehingga ketika musim hujan terjadi maka banyak pepohonan dan daun-daun terendam air dan dalam waktu tertentu mengalami proses pelapukan oleh bakteri yang menghasilkan unsur nitrat ataupun fosfat.

Effendi (2003) menyatakan bahwa sumber nitrat dapat juga berasal dari proses dekomposisi bahan-bahan organik (tumbuhan dan biota akuatik yang sudah mati) diurai oleh bakteri Nitrobacter menjadi nitrat. Sedangkan fosfat menurut Fachrul et al. (2005) menyatakan bahwa senyawa fosfat dalam perairan dapat berasal dari sumber alami seperti erosi tanah, buangan dari hewan dan lapukan tumbuhtumbuhan.

\section{Kesimpulan}

Dari hasil penelitian yang dilakukan dapat disimpulkan sebagai berikut:

1. Tingkat kesuburanperairan kolam Agrowisata UIR ditinjau dari konsentrasi klorofil-a phytoplankton tergolong cukup produktif (sedang).

2. Konsentrasi klorofil-a berada pada rata-rata 1-20 $\mu \mathrm{g} / \mathrm{l}$ dengan kelimpahan phytoplankton secara keseluruhan di kolam tersebut berada pada rata-rata $10^{4} \mathrm{sel} / \mathrm{l}$.

3. Kelimpahan pada phytoplankton mempunyai hubungan yang positif terhadap nilai konsentrasi klorofil-a di perairan kolam Agrowisata UIR.

4. Kualitas air selama penelitian terhitung cukup baik yaitu dengan suhu berkisar antara 28,4-29,4 $4^{\circ}$ C, kecerahan 29,0-29,7 $\mathrm{cm}, \mathrm{pH} 6,00-6,07, \mathrm{DO} 4,28-4,88 \mathrm{mg} / \mathrm{l}, \mathrm{CO}_{2}$ bebas $5,26-5,76 \mathrm{mg} / \mathrm{l}$, nitrat $0,0667-0,0733$ $\mathrm{mg} / \mathrm{l}$ dan fosfat $0,0070-0,0083 \mathrm{mg} / \mathrm{l}$.

\section{Saran}

Mengingat pengambilan sampel klorofil-a saat penelitian hanya dilakukan pada permukaan saja (kedalaman secchi disk), maka perlu pengambilan sampel pada beberapa kedalaman perairan yang berbeda-beda untuk melihat variasi konsentrasi klorofil-a secara vertikal pada tiap kedalaman. Rekomendasi untuk usaha budidaya perikanan sangat baik untuk terus 
dimanfaatkan secara terpadu karena kolam ini sudah memiliki persyaratan yang memungkinkan untuk usaha ini, baik dilihat dari konsentrasi klorofil-a phytoplankton dan kelimpahan phytoplankton yang dapat dijadikan sebagai pakan alami maupun kualitas air yang cukup memadai.

\section{DAFTAR PUSTAKA}

Boney, A. D. 1975. Pytoplankton. Edward Arnold Ltd. London, 116 pp.

Boyd, C. E., 1979. Water Quality in Warm Water Fish Pon. Auburn University. Agricultural Experiment Station. Auburn, $359 \mathrm{p}$.

Chakroff, M., 1979. Freswater Pond Cultur and Management. Vita Publication. London, $191 \mathrm{p}$.

Effendi, H., 2003. Telaah Kualitas Air Bagi Pengelolaan Sumberdaya dan Lingkungan Perairan. Kanisius, Yogyakarta, 258 hal.

Fachrul, M. F, H. Herman dan C. S. Listari. 2005. Komunitas Fitoplankton Sebagai Bio-indikator Kualitas Perairan Teluk Jakarta. Fakultas Arsitektur Lanskep Teknologi Lingkungan Universitas Trisakti dalam Seminar Nasional MIPA. Universitas Indonesia. Depok. www.Rudyct.com. Di akses tanggal 20 Maret 2016.

Hatta, M., 2002. Hubungan antara klorofil-a dan Ikan Pelagis dengan Kondisi Oseanografi di Perairan Utara Irian Jaya. Makalah Falsafah Sains (PPS 702). Program Pasca Sarjana / S2. Institut Pertanian Bogor. http://tumoutou.net/3-sem1-012/muhhatta.htm.Di akses tanggal 5 Desember 2015.

Nybakken, J.W. 1992. Biologi Laut suatu Pendekatan Biologis. Diterjemah oleh H. M. Eidman, Koesoebiono, D.G, Bengen, M. Hutomo dan S. Suharjo. Gramedia, Jakarta. 459 hal.

Odum, E. P. 1971. Fundamentals of Ecology. W. B.Saunders and Co., Philadelphia, 574 pp.

Sachlan, M., 1980. Planktonologi. Diktat Kuliah Fakultas Perikanan Institut Pertanian Bogor. Bogor, 116 hal.

Sediadi, A dan P. H. Lusikooy.1991. Distribusi Fitoplankton dan Klorofil-a di Perairan Teluk Tuhha Maluku Tengah. Jurnal Perikanan Universitas Samratulangi, Ambon, 34 hal.
Simarmata, A.H. 2007. Kajian Keterkaitan antara Kemantapan Cadangan Oksigen dengan Beban Masukan Bahan Organik di Waduk Ir. H. Juanda Purwakarta Jawa Barat. Disertasi. Bogor: Institut Pertanian Bogor. Bogor, 116 hal.

Tambaru, R., 2003. Selang Waktu Inkubasi yang Terbaik dalam Pengukuran Produktifitas Primer Fitoplankton di Perairan Laut. Makalah Falsafah Sains, Program Pasca Sarjana. S3. Institut Pertanian Bogor. Bogor, 189 hal (tidak diterbitkan).

Wellch, P. S., 1984. Limnology. $2^{\text {nd }}$ Edition. Mc Graw Hill Book Company. New York. $381 \mathrm{p}$. 
